Review

\title{
c-Met and Other Cell Surface Molecules: Interaction, Activation and Functional Consequences
}

\author{
Giuditta Viticchiè and Patricia A. J. Muller * \\ MRC (Medical Research Council) Toxicology Unit, Lancaster Road, Leicester LE1 9HN, UK; \\ E-Mail: gv34@le.ac.uk \\ * Author to whom correspondence should be addressed; E-Mail: pm292@le.ac.uk; \\ Tel.: +44-116-252-2930; Fax: +44-116-252-5616.
}

Academic Editor: Giulia Ricci

Received: 29 September 2014 / Accepted: 8 January 2015 / Published: 15 January 2015

\begin{abstract}
The c-Met receptor, also known as the HGF receptor, is one of the most studied tyrosine kinase receptors, yet its biological functions and activation mechanisms are still not fully understood. c-Met has been implicated in embryonic development and organogenesis, in tissue remodelling homeostasis and repair and in cancer metastasis. These functions are indicative of the many cellular processes in which the receptor plays a role, including cell motility, scattering, survival and proliferation. In the context of malignancy, sustained activation of c-Met leads to a signalling cascade involving a multitude of kinases that initiate an invasive and metastatic program. Many proteins can affect the activation of c-Met, including a variety of other cell surface and membrane-spanning molecules or receptors. Some cell surface molecules share structural homology with the c-Met extracellular domain and can activate c-Met via clustering through this domain (e.g., plexins), whereas other receptor tyrosine kinases can enhance c-Met activation and signalling through intracellular signalling cascades (e.g., EGFR). In this review, we provide an overview of c-Met interactions and crosstalk with partner molecules and the functional consequences of these interactions on c-Met activation and downstream signalling, c-Met intracellular localization/recycling and c-Met degradation.
\end{abstract}

Keywords: c-Met; HGF receptor; RTK; recycling; crosstalk 


\section{Introduction}

c-Met, also known as the scatter factor receptor, is one of the major players in invasive growth [1] and morphogenetic events during embryogenesis and adult life [2]. c-Met was first identified as a member of the receptor tyrosine kinases family (RTKs) in 1987 [3] and has since attracted widespread interest because of its aberrant activation during the malignant progression of various cancers. Upon binding to its ligand, hepatocyte growth factor (HGF), c-Met triggers the induction of several downstream signalling cascades leading to a multitude of outcomes: increased survival, proliferation, anchorage-independent growth, enhanced motility, migration, scattering, metastasis and invasion [4-10].

\section{2. c-Met Structure and Activation}

c-Met is a heterodimer consisting of an extracellular $\alpha$-chain bound through a disulphide bridge to a transmembrane $\beta$-chain [11]. The structure comprises several domains, including a SEMA domain (semaphorin like domain), a PSI domain (plexin-semaphorin-integrin domain) and four IPT domains (immunoglobulin-plexin-transcription factor domain) that share structural homologies with plexins, integrins, semaphorins and immunoglobulins [12]. As soon as HGF is recognized by the immunoglobulin-like domains, two c-Met heterodimers dimerize, leading to the autophosphorylation of two tyrosine residues within the catalytic loop (Tyr1234-Tyr1235). Subsequently, further autophosphorylation of two tyrosines (Tyr1349-Tyr1356) in the $C$-terminal domain provide the docking platform for the recruitment of other molecular interactors and signal conveyors [13] (Figure 1). Among these are the Grb2-associated binding protein 1 (Gab1) that supplies binding sites for Src-homology-2 domain (SH2)-containing effectors, like the SH2-transforming protein (SHC), "the phosphoinositide 3 kinase (PI3K), the SH2-domain containing protein tyrosine phosphatase (SHP2), the phospholipase C $\gamma 1$ (PLC $\gamma 1$ ), the signal transducer and activator of transcription 3 (STAT3) and the Ras GTPase p120 [7-9,14-16]. Most of the cellular responses induced by c-Met activation are mediated by the action of the adaptor molecule, Gab1 [9,17,18]. A sequence of 13 amino acids, identified as the c-Met binding site, is responsible for the direct association of Gab1 to c-Met, leading to the assembly of the docking platform [7,17,18]. Gab1 activity and function are enhanced and prolonged upon HGF-dependent phosphorylation of tyrosine residues in Gab1 that provide extra binding sites for the recruitment of the aforementioned signal transducer and docking proteins. Consequently, by acting as a molecular bridge to unleash c-Met signalling, Gab1 functions as an upstream initiator of the Ras-ERKs/MAPKs cascade.

To regulate the intensity of the c-Met signal, another group of proteins regulate the duration of c-Met activity through dephosphorylation of the catalytic and docking tyrosines. These phosphatase tyrosine proteins (PTPs), including the receptor, PTPs density-enhanced phosphatase 1 (DEP1), the non-receptor, PTPs PTP1B, leukocyte common antigen-related (LAR) and T-cell PTP (TCPTP), act as antagonistic c-Met partners in order to prevent prolonged c-Met signalling [19-21]. 
A.

口 Dephospho-Tyr

口 Catalytic Phospho-Tyr

HGF

口 Docking Phospho-Tyr
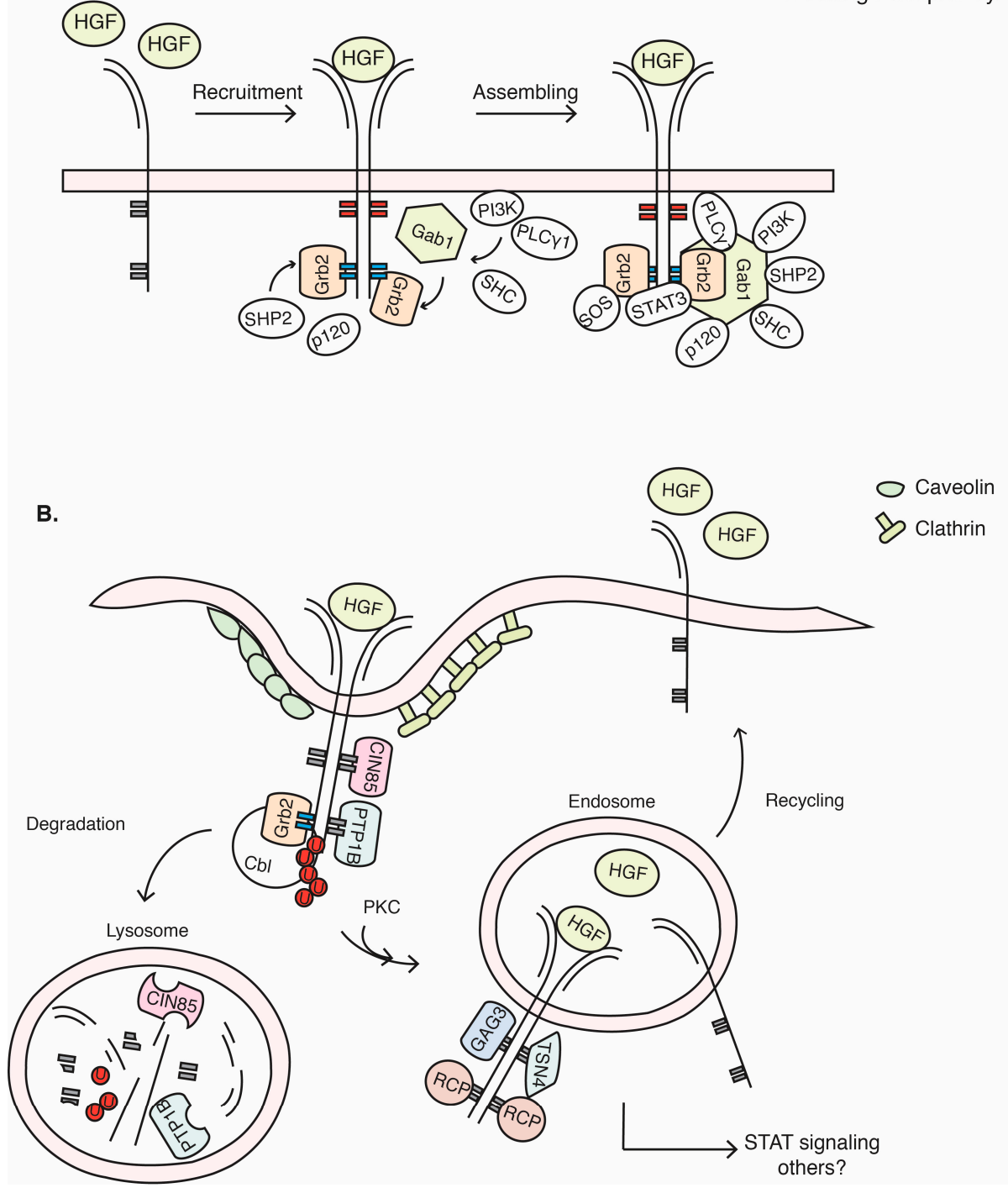

Figure 1. Activation, signalling, internalization and recycling of c-Met. (A) Representation of the activation of the c-Met heterodimer illustrating the catalytic and docking tyrosine residues in the non-phosphorylated inactive state, non-HGF-bound state (left) or the active state (right). HGF-mediated c-Met activation triggers the sequential trans-phosphorylation of catalytic tyrosines (Tyr1234-1235, red residues) and docking tyrosines (Tyr1349-1356, blue residues), determining the biochemical signature for the further recruitment of amplifier and transducer molecules. Grb2 and STAT3 directly associate with the c-Met carboxy-terminal tail, while Gab1 interacts both indirectly (through Grb2) or directly providing a docking structure for SHC, PI3K, SHP2, PLC $\gamma 1$ and p120, resulting in activation of the downstream signalling pathways; (B) Representation of the internalization and recycling of c-Met. To prevent c-Met over-stimulation, several protein-tyrosine phosphatases downregulate the c-Met signal, reverting the catalytic and docking tyrosines to a non-phosphorylated inactive state. The dissociation of the intermediate molecules from the complex refines the tuning and timing of the c-Met-mediated biological response and allows further internalization of c-Met. The Cb1 E3 ubiquitin ligase mediates ubiquitination of c-Met, providing a signal for c-Met internalization, which has been shown to be 
clathrin- or caveolin-dependent. Internalization can be enhanced by Grb2, CIN85, SNX2, CD44v6 and PTP1B. Once internalized, the c-Met receptor can be delivered to lysosomes to be degraded or it can be recycled back to the plasma membrane through the endosomal compartments. PKCe is important for the delivery towards the endosomes, from which the c-Met receptor can signal to specific signalling routes, including STAT3. Recycling back to the plasma membrane has been shown to be dependent on RCP, GGA3 and/or TSN4.

\section{3. c-Met Signalling Cascade}

Activation and crosstalk between several signalling pathways has been described following stimulation of the c-Met receptor with its ligand, HGF, leading to a global change in gene expression [22,23].

The mitogen-activated protein kinases (MAPKs) and the extracellular signal-regulated kinases (ERK1/2) are among the major c-Met executors downstream of c-Met activation and interaction with docking molecules [24]. Two main transducer pathways have been shown to link phosphorylated c-Met to the MAPK/ERK components; one involving activation of Ras small GTPase following the association of Grb2-son of sevenless protein (SOS) complex to the c-Met $C$-terminus [13] and one involving Ras inhibiting protein p120 deactivation upon c-Met-Gab1-SHP2 interaction [25]. Both of these steps result in translocation of ERKs to the nucleus to promote ETS/AP1-mediated transcriptional regulation of cell cycle modulators and adhesion proteins in order to control cell proliferation and motility [5-9,26]. c-Met can also activate the Jun amino-terminal kinases (JNKs) and p38 MAPKs via the same pathways, thereby regulating cytoskeleton-associated proteins that are important in cell migration and scattering [10,27]. Alternatively, PI3K was found to be directly activated by c-Met or indirectly by Ras-driven Akt/PKB signalling, which, in turn, leads to BCL2 antagonist of cell death (Bad) inactivation and to MDM2-mediated p53 degradation, promoting enhanced cell survival [28-30]. STAT3 associates with phosphorylated c-Met and undergoes phosphorylation itself, after which it translocates into the nucleus and increases transcription of genes involved in tumourigenesis $[31,32]$.

\section{4. c-Met Endocytosis and Recycling}

As with all growth factor-induced receptors, ligand-induced signalling through c-Met is tightly controlled. One of the control mechanisms comprises the rapid internalization and degradation/recycling of the receptor in a process called receptor-mediated endocytosis [33]. The rapid removal of the receptor from the plasma membrane was described as an important mechanism by which cells quickly switch off further signalling to prevent sustained stimulation of the receptor, which can otherwise promote transformation [33]. Ligand stimulation of c-Met leads to polyubiquitinated c-Met and proteasomal degradation upon c-Met internalization [34]. Petrelli et al. demonstrated that internalization and degradation was dependent on c-Met binding to the endophilins, CIN85 and Cbl, through a process of clathrin-coated vesicle formation [35]. However, more recently, clathrin-independent endocytosis of the c-Met receptor through interaction with caveolin has also been demonstrated [36]. A pivotal role for $\mathrm{Cbl}$ in c-Met degradation was confirmed by $\mathrm{Li}$ et al. and provided evidence that the signalling adaptor protein, Grb2, is required for c-Met endocytosis [37]. Other factors involved in c-Met internalization are dorsal ruffle formation [38], sorting nexin 2 (SNX2) [39] and the c-Met interaction partner, CD44v6 [40] (see the CD44 section). Upon internalization, the endoplasmic reticulum-localized 
protein-tyrosine phosphatase 1B (PTP1B) and dynamin were found to coordinate the early events of endosome formation that dictate c-Met trafficking and degradation $[34,41,42]$. The fact that $\mathrm{Cbl}$ can promote degradation, but is not required for internalization [37], suggests that c-Met endocytosis and c-Met degradation are different processes that might serve different purposes. Indeed, it has been suggested that the compartmentalization of growth factor receptors plays a crucial role in the signal transduction process and that rather than being just destined for irreversible degradation, the endocytic vesicles might provide a modulatory substation that retains a targeted receptor to act at the right time at the right place with the right signalling output [43]. Evidence that c-Met localization determines signalling is provided by Kermogant et al., who showed that the translocation of c-Met from the endosomal compartment to the perinuclear compartment is dependent on $\mathrm{PKC} \alpha$, and inhibition of PKC $\alpha$ resulted in a decreased signalling of c-Met to STAT3 [44]. The same group also revealed that c-Met signalling to Rac1 is differently regulated from c-Met localized in peripheral endosomes than in perinuclear endosomes [45]. Trafficking to the perinuclear regions depends on an interaction with PKC $\varepsilon$, which was demonstrated to be important for $p$-ERK1/2 accumulation at focal complexes upon c-Met activation [46].

Furthermore, various groups have provided evidence that endosomal-localized c-Met is not just destined to be degraded, but can be returned to the plasma membrane in a process that is called receptor recycling. Receptor recycling has long been demonstrated for another RTK, EGFR [47], and provides a means to sustain downstream signalling. Using c-Met mutant proteins that were found in renal cancers, Joffre et al. showed that the mutant versions of c-Met underwent an increased Cb1-Grb2-dependent recycling and a concomitant aberrant activation of GTPase Rac1, leading to enhanced cell migration, anchorage-independent cell growth and in vivo tumorigenesis [48]. Proteins that have been implicated in recycling back to the plasma membrane include Hrs, Golgi-localized $\gamma$-ear-containing Arf-binding protein 3 (GGA3), Tensin-4 and Rab coupling protein (RCP) [49-52] (Figure 1). The proteasomal inhibitor, lactacystin, promotes c-Met recycling back to the plasma membrane, possibly through preventing c-Met from entering the lysosomal degradation pathway. Lactacystin treatment coincided with a decrease in the endosomal sorting protein, Hrs, and siRNA-mediated Hrs inhibition promoted c-Met activity, suggesting that Hrs dictates c-Met degradation [49]. The adaptor protein, GGA3, interacts with activated c-Met to promote its recycling, and loss of GGA3 resulted in attenuated ERK1/2 activation and pronounced c-Met degradation [52]. Tensins are scaffold proteins that are known for their role in coupling integrin receptors to the cytoskeleton. TNS4, unlike the other tensins, abrogates this link and promotes cell migration. TNS4 was found to also interact with c-Met and to promote its recycling to the plasma membrane to prevent degradation in an integrin-independent manner [50]. Remarkably, we identified that another integrin binding partner, RCP, could also promote c-Met recycling in cells dependent on the expression of an oncogenic mutant p53 protein [53]. Loss of RCP in mutant p53-expressing cells decreased the recycling of c-Met back to the plasma membrane, thereby attenuating ERK1/2 signalling and decreasing cell invasion and cell scattering. These data suggest that the imbalance between recycling and degradation in favour of continuous endosomal trafficking contributes to the maintenance of the activated state of c-Met, leading to pro-malignant signalling. 


\section{5. c-Met and Its Membrane-Spanning Partner Molecules}

c-Met signalling, degradation, activation and intracellular localization are not only determined by the docking and signalling molecules described so far, but can also be modulated by a large variety of c-Met interacting molecules comprising membrane spanning proteins and receptors, which include plexins, integrins, semaphorins and other RTKs (Table 1 and Figure 2). These proteins interact with c-Met and potentiate, inhibit or modulate the downstream signalling of c-Met, as explained below.

Table 1. c-Met interacting proteins and their function on c-Met.

\begin{tabular}{|c|c|c|c|c|c|}
\hline Receptor & & Cell System & Effect on c-Met & Biological Response & Reference \\
\hline \multirow{5}{*}{ Plexins } & \multirow{4}{*}{ Plexin B1 } & HUVEC & Inhibition & $\downarrow$ Angiogenesis & {$[54]$} \\
\hline & & HT-29 & Activation & $\uparrow$ Invasion & {$[55]$} \\
\hline & & SK-BR3, MLP29 & Activation & $\begin{array}{l}\uparrow \text { Migration } \\
\uparrow \text { Colony formation, } \\
\uparrow \text { Invasive growth }\end{array}$ & {$[56]$} \\
\hline & & YUSIK, MDA-MB 468, MCF-7 & Inhibition & $\downarrow$ Migration & {$[57-60]$} \\
\hline & Plexin B3 & HUVECs & Activation & $\uparrow$ Migration & [61] \\
\hline \multirow{5}{*}{ CD44 } & $\mathrm{CD} 44 \mathrm{v} 9$ & C4-2, LNCap & Activation & $\uparrow$ Resistance, invasion & {$[62]$} \\
\hline & \multirow{3}{*}{ CD44v6 } & WM9, WM164, 1205Lu & Activation & $\uparrow$ Migration & {$[63]$} \\
\hline & & HeLa, HT29, HepG2 & Activation & $\begin{array}{l}\uparrow \mathrm{c}-\text { Met internalization, } \\
\text { signalling, scattering }\end{array}$ & {$[40,64,65]$} \\
\hline & & fibroblasts & Activation & $\uparrow$ Proliferation & {$[66]$} \\
\hline & $\mathrm{CD} 44 \mathrm{v} 10$ & $\begin{array}{l}\text { Human pulmonary microvascular } \\
\text { EC, B-cells }\end{array}$ & Activation & $\begin{array}{l}\uparrow \text { EC barrier enhancement, } \\
\text { B-cell survival }\end{array}$ & {$[67,68]$} \\
\hline \multirow{7}{*}{ Tetraspanin } & \multirow[b]{3}{*}{ CD151 } & AccM, Acc2 & Activation & $\uparrow$ Migration, proliferation & [69] \\
\hline & & MDA-MB-231 & Activation & $\uparrow$ Branching morphogenesis & {$[70]$} \\
\hline & & GTL-16 & Activation & $\begin{array}{l}\uparrow \text { Proliferation, } \\
\text { anchorage-independent } \\
\text { growth }\end{array}$ & {$[71]$} \\
\hline & \multirow{4}{*}{ CD82 } & PC3, Hepa1-6 & Inhibition & $\downarrow$ Migration, invasion & {$[72,73]$} \\
\hline & & Oligodendrocytes $\left(\mathrm{O}^{+}\right.$cells $)$ & Inhibition & $\downarrow$ Differentiation & [74] \\
\hline & & HCV29/YTS1 & Inhibition & $\downarrow$ Invasion & {$[75]$} \\
\hline & & H1299 & Inhibition & $\begin{array}{l}\downarrow \text { Migration, } \\
\text { lamellipodia formation }\end{array}$ & {$[76]$} \\
\hline \multirow{9}{*}{ Integrin } & \multirow{4}{*}{$\alpha 6 \beta 4$} & GTL-16, A431, MDA-MB-435 & Activation & $\uparrow$ Invasive growth & {$[71,77]$} \\
\hline & & MEFs & Activation & $\begin{array}{l}\uparrow \text { Colony formation, } \\
\text { tumour growth }\end{array}$ & {$[78]$} \\
\hline & & DU145 & Activation & $\uparrow$ Self-renewal, invasion & [79] \\
\hline & & HLMVEC, HPAEC & Activation & EC barrier integrity & {$[80]$} \\
\hline & \multirow{2}{*}{$\alpha 5 \beta 1$} & HMVEC & Activation & $\uparrow$ Migration, proliferation & {$[81]$} \\
\hline & & SKOV3ip1, HeyA8 & Activation & $\uparrow$ Metastasis & {$[82]$} \\
\hline & $\alpha 3 \beta 1$ & Mouse papillary cells & Activation & Kidney morphogenesis & {$[83]$} \\
\hline & $\alpha \times \beta 1$ & PC9 & Activation & $\uparrow$ Proliferation & {$[84]$} \\
\hline & $\alpha 2 \beta 1$ & PMCs & Activation & $\uparrow \mathrm{PMC}$ activation & {$[85]$} \\
\hline
\end{tabular}


Table 1. Cont.

\begin{tabular}{|c|c|c|c|c|c|}
\hline Receptor & & Cell System & Effect on c-Met & Biological Response & Reference \\
\hline \multirow{20}{*}{ RTKs } & Ron & NIH3T3 & $\begin{array}{l}\text { Reciprocal } \\
\text { Activation }\end{array}$ & $\uparrow$ Colony formation & {$[86]$} \\
\hline & \multirow{11}{*}{ EGFR } & $\begin{array}{l}\text { A431, HepG2, AKN-1, HuH6, } \\
\text { MRC5 }\end{array}$ & Activation & $\uparrow \mathrm{c}-$ Met signalling & {$[87]$} \\
\hline & & $\begin{array}{l}\text { PyVmT, MDA-MB231, 4T1, } \\
\text { NCl H596, DLD1, HT29 }\end{array}$ & Activation & $\uparrow$ Motility, proliferation & [88-90] \\
\hline & & $\begin{array}{l}\text { PC-9, HCC827, SNU-16, MKN45, } \\
\text { BT474, SKBR3 }\end{array}$ & Activation & $\uparrow$ Drug resistance & [91-93] \\
\hline & & 5637 tumour bladder cell line & Activation & $\uparrow$ Survival, cell growth & [94] \\
\hline & & ARPE-19 & $\begin{array}{l}\text { Activation, } \\
\text { Ecto-domain } \\
\text { shedding }\end{array}$ & $\uparrow$ Wound healing & {$[95]$} \\
\hline & & A549 & $\begin{array}{l}\text { Ecto-domain } \\
\text { shedding }\end{array}$ & NA & {$[96]$} \\
\hline & & H1993, EBC1 & Activation & $\uparrow$ Survival, proliferation & [97] \\
\hline & & H1975, H520, A549 & Activation & $\begin{array}{l}\uparrow \text { Tumour growth and } \\
\text { survival }\end{array}$ & {$[98]$} \\
\hline & & GEO-CR, SW48-CR & Activation & $\begin{array}{l}\uparrow \mathrm{c}-\text { Met phosphorylation, } \\
\uparrow \text { Survival }\end{array}$ & [99] \\
\hline & & 32D, PC9 & Activation & $\begin{array}{l}\uparrow \text { c-Met phosphorylation, } \\
\text { metastasis, invasion and } \\
\text { colony formation }\end{array}$ & {$[100]$} \\
\hline & & 201T, A549 & Activation & $\begin{array}{l}\uparrow \mathrm{c}-\text { Met phosphorylation, } \\
\text { xenograft growth }\end{array}$ & [101] \\
\hline & \multirow{3}{*}{ Her2 } & SK-BR3, BT474 & Activation & $\uparrow$ Drug resistance & [102] \\
\hline & & H1993, EBC1 & Activation & $\begin{array}{l}\uparrow \text { Survival, proliferation, } \\
\uparrow \text { Migration }\end{array}$ & {$[97]$} \\
\hline & & MDCK & Activation & $\uparrow \mathrm{EMT}$ & [103] \\
\hline & \multirow{3}{*}{ Her3 } & H1993, EBC1 & Activation & $\uparrow$ Survival, proliferation & [97] \\
\hline & & HCC827, & $\begin{array}{l}\text { NA (HER3 } \\
\text { activation) } *\end{array}$ & $\uparrow$ Drug resistance & [104] \\
\hline & & MKN45, GTL16 & Activation & $\uparrow$ Drug resistance & {$[91,105]$} \\
\hline & IGFR & L3.6pl & Activation & $\uparrow$ Migration, invasion & [106] \\
\hline & RET & H1993, EBC1 & Activation & $\uparrow$ Migration & [97] \\
\hline \multirow{3}{*}{$\begin{array}{l}\text { Death } \\
\text { receptors }\end{array}$} & \multirow{2}{*}{ Fas } & HepG2, Hepa1-6 & No effect & $\downarrow$ Apoptosis & {$[107,108]$} \\
\hline & & HUVECs & NA & $\downarrow$ Apoptosis & [109] \\
\hline & DR5 & Medulloblastoma/glioma cell lines & NA & $\downarrow$ Apoptosis & {$[110]$} \\
\hline \multirow[t]{2}{*}{ Mucins } & Muc1 & $\begin{array}{l}\text { Panc-1, HPAF2, MDA-MB-435, } \\
\text { Mahlavu, SNU-449 }\end{array}$ & Inhibition & $\downarrow$ Invasion, EMT & [111-113] \\
\hline & Muc20 & HEK293, CHO-K1 & Inhibition & $\downarrow$ Invasion, EMT & [114] \\
\hline NRP1 & & PCa cells & Activation & $\uparrow$ Bone metastasis & {$[115]$} \\
\hline ICAM1 & & HT29, HepG2 & Activation & $\uparrow$ Proliferation & [116] \\
\hline
\end{tabular}

* Cooperation between c-Met and EGFR was seen, but c-Met activation was not directly determined. 
A

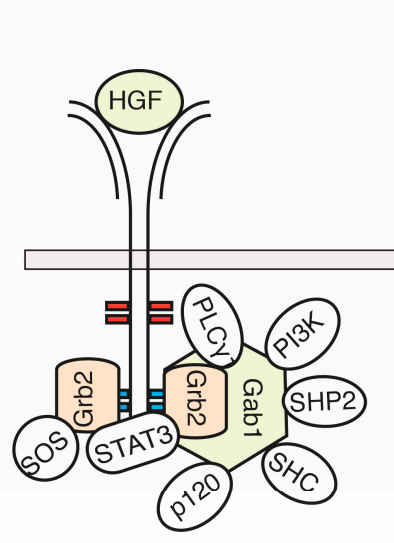

Scattering
Migration Invasive growth

Proiferation

Angiogenesis
B

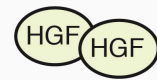

C

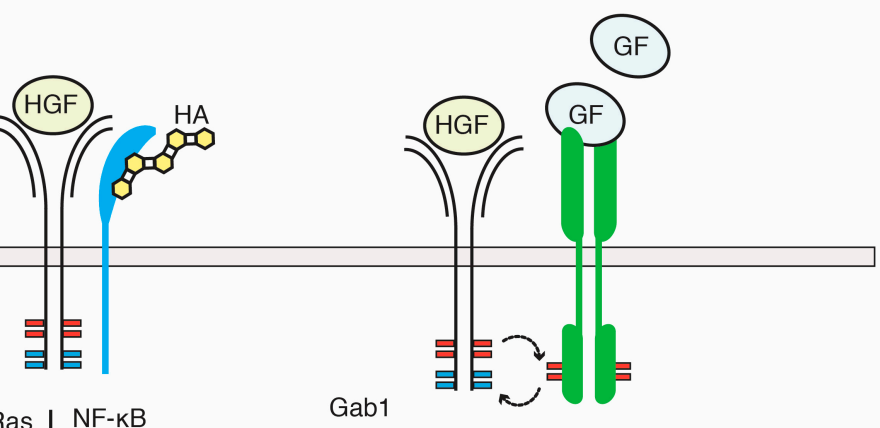

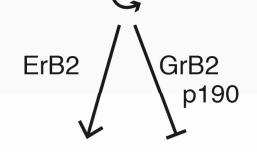

Invasion

Migration Angiogenesis

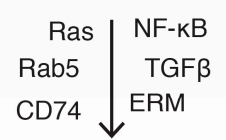

c-Met recycling Scattering Invasion

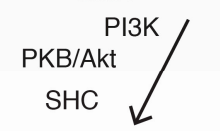

Drug resistance Proliferation Motility

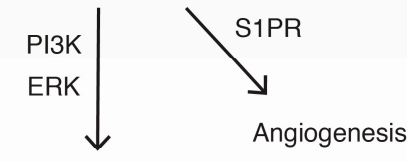

Wound healing

EMT

Angiogenesis
E

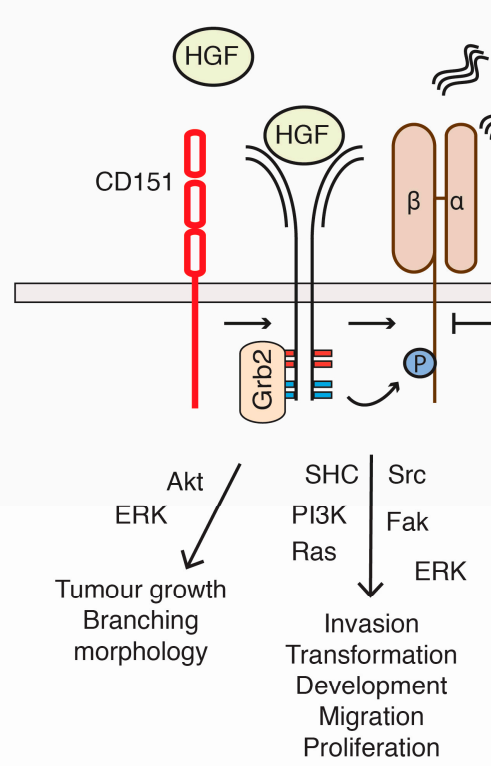

F
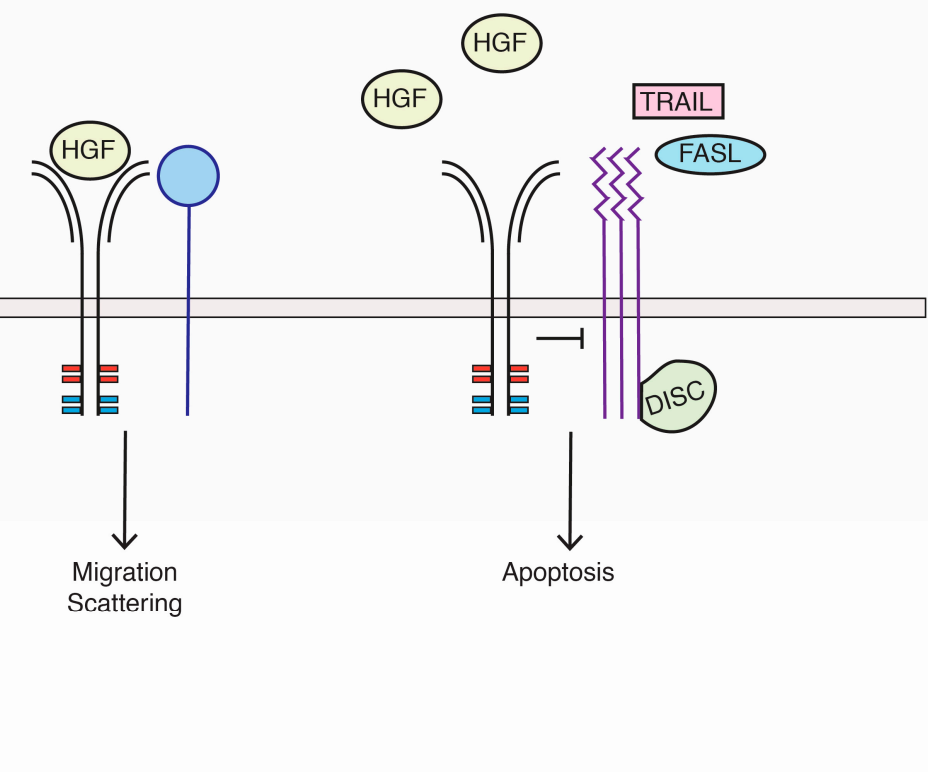

G

legend:

a-Met Plexin B1 B $\begin{gathered}\text { Semaphorin } \\ 4 \mathrm{~B}\end{gathered}$ CD44 \& $\begin{gathered}\text { Hyaluronic } \\ \text { acid }\end{gathered}$ RTK (GF) $\begin{gathered}\text { Growth } \\ \text { Factor }\end{gathered}$

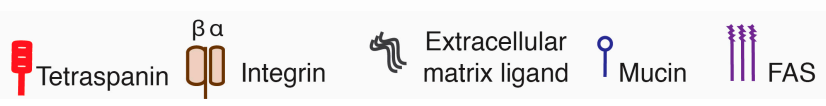

Figure 2. Membrane molecules that interact with and influence c-Met function. c-Met interacts with a variety of other cell membrane molecules and receptors that can modulate c-Met signalling and cellular outcome. (A) Signalling of the c-Met dimer alone; (B) The plexin $\mathrm{B} 1$ extracellular domain has been found to associate with the c-Met counterpart, enhancing ErB2-mediated invasion or repressing c-Met through GrB2-p190 to promote invasion, migration and/or angiogenesis; (C) CD44 family members physically bind to c-Met to 
promote its internalization, which promoted c-Met-dependent invasion and migration; (D) Among the RTKs, the EGFR association with c-Met has been most studied. Many RTKs can transphosphorylate c-Met tyrosine residues and thereby amplify c-Met-signalling to promote drug resistance, EMT or wound healing. EGFR also promotes c-Met ectodomain shedding, which is not depicted in this figure; (E) Integrins associate with c-Met, enhancing its transforming potential. In detail, HGF and extracellular matrix proteins participate in c-Met/integrin binding, promoting migration and proliferation in a Ras- or Src-dependent manner. Tetraspanins were found to modulate integrin/c-Met function; (F) Mucins inhibit c-Met via unknown mechanisms, leading to decreased HGF-driven migration and scattering; (G) Inactive c-Met can prevent FasL- or TRAIL-driven Fas or DR5 complex formation, with TRAIL resulting in decreased apoptotic signalling.

\subsection{Plexin Proteins}

Plexins are transmembrane receptors originally discovered as main regulators of semaphorin signalling [117]. They activate downstream signalling pathways, related to cytoskeleton remodelling, via a variety of specific small Rho GTPases, determining cell migration and invasion $[118,119]$. In the context of RTK crosstalk, the high structural homology of the extracellular domain with plexins, which include a propeller structure involved in protein-protein interactions, make plexin family members good molecular partners for a variety of RTKs [55]. With respect to c-Met, plexin B1 and its ligand, semaphorin 4D, have been most studied, and both have been implicated in cancer progression [120]. The precise role of the plexin B1/Sema4D signalling axis in the malignant phenotype is still unknown, and several reports demonstrate functions both inhibiting and promoting malignancy [120]. This diversity is also reflected in the observation that plexins have opposing roles on c-Met function. Conrotto et al. and Giordano et al. both demonstrated a role for Sema4D to promote c-Met activation and signalling through binding with the plexin B1 receptor in epithelial cells, resulting in increased invasion and migration [55,56]. Others, however, revealed in various systems an inhibitory role for plexin B1 on c-Met function through direct binding, leading to decreased cell migration and decreased angiogenesis [54,57-59]. In breast cancer cell lines, plexin B1 was found to be phosphorylated by c-Met, leading to Grb2 (growth factor receptor bound-2) recruitment to the plexin B1/c-Met complex [59]. Grb2 subsequently recruited p190 RhoGAP, resulting in RhoA deactivation and suppression of cell migration. The differential function of Sema4D/plexin in tumour biology is also illustrated by the variable results in studies examining the expression levels of these molecules in the disease progression of human cancers with both low Sem4D and high plexin-B1, leading to poorer survival $[55,56,60,61]$.

The differential role of the plexin B1/Sema4D/c-Met signalling axis in cell migration could be related to the expression of the RTK, ErbB2. While plexin B1 triggered increased cell invasion of LNCaP cells in an ErbB2-dependent manner, PC3 cells highly expressing c-Met displayed decreased motility after plexin B1 activation [121]. Similarly, MDA MB468 cells that express high levels of c-Met were inhibited in cell migration upon Sema4D-induced plexin B1 activation, while migration of MCF7 cells that express high levels of ErbB2 was increased under the same circumstances [60]. Interestingly, the effect on MCF7 could be reversed by knockdown of ErbB2 and overexpression of c-Met. In addition, overexpression of ErbB2 diminished the binding of c-Met to plexin B1, suggesting 
that in breast cancer cells and in prostate cancer cells, ErbB2 and c-Met are competing for plexin B1 binding, which largely determines the cellular outcome of Sema4D signalling. However, ErbB2 expression levels cannot explain the promoting effect of plexin B1 on c-Met function seen by Giordano et al. and Conrotto et al. [55,56], and it seems likely that other factors must play a role in determining c-Met function in relation to plexin B1 binding. c-Met was also found to interact with another plexin, plexin B3, leading to c-Met activation, leading to increased migration of HUVEC cells [61]. It will be interesting to see whether ErbB2 or other RTKs can influence this interaction and whether c-Met can be regulated by other members of the plexin family.

\subsection{CD44 Proteins}

CD44 glycoproteins are a family of transmembrane proteins transcribed from one mRNA that undergoes alternative splicing to generate multiple isoforms [122]. Ligands for CD44 are hyaluronic acid and osteopontin, which can promote tumour cell growth and chemotaxis, respectively [122]. A role for CD44 in the HGF signalling path was first described by van der Voort et al. [123], showing that CD44 promotes HGF signalling through c-Met. Mice that have been engineered to lose CD44 expression display haploinsufficiency for c-Met, demonstrating a role for CD44 and c-Met collaboration in vivo [124]. An interaction between c-Met and CD44 proteins was shown by Orian-Rousseau et al. revealing that HGF-dependent scattering and invasion of several cancer cell lines and primary cells require the function of the CD44v6 isoform [64]. This CD44v6 isoform was required for c-Met autophosphorylation and downstream signalling through interaction with ERM (Ezrin, radixin and moesin) proteins that link the actin cytoskeleton to the cellular membrane $[64,65,125]$ and Ezrin phosphorylation indeed is required for HGF-induced cell scattering and morphogenesis [125]. Through this link with the ERM proteins, CD44v6 promotes the internalization of c-Met to a rab5-positive endosomal compartment from which c-Met promoted downstream signalling [40]. Some other studies have since confirmed that overexpression of this particular isoform of CD44 in different tumour cell systems promotes c-Met function and is involved in the crosstalk between c-Met and the NF- $\mathrm{BB}$ or the TGF- $\beta 1$ signalling pathways $[63,66]$. The role of a co-receptor linking c-Met to ERM proteins is not exclusive to CD44v6, as more recently, ICAM1 was shown to fulfil a similar role in the absence of CD44v6 on c-Met function [116].

Other CD44 isoforms have similarly been shown to promote c-Met function. In prostate cancer cell lines, HGF-dependent activation of c-Met stimulated hyaluronan/CD44v9 signalling, which stabilized the androgen receptor and promoted its function [62]. Singleton et al. demonstrated that CD44 proteins are important regulators of c-Met-mediated vascular barrier enhancement. This process involves the association of CD44v10 with HGF-activated c-Met and its further translocation into Caveolin-enriched microdomains (CEMs, also named lipid rafts) on the cell membrane [68]. The CD44v10/c-Met then recruits Tiam1, cortactin and/or dynamin 2 proteins, providing the components for proper CEM scaffolding that preserves vascular endothelial cell barrier integrity. In summary, these data demonstrate that various CD44 isoforms have a positive role in c-Met functioning by promoting c-Met coupling to the ERM proteins, interaction with other signalling pathways and c-Met localization to specific microdomains on the cellular membrane. 


\subsection{Integrins}

Integrins are heterodimeric membrane receptors responsible for the adhesive interactions between the cell and its surroundings, including the extracellular matrix and neighbouring cells [126]. They exert this scaffold function through the recruitment of a complex network of proteins that connect the actin cytoskeleton to extracellular components [127]. Besides promoting the assembly of tissues with specific physical and mechanical properties, they are also important molecular transducers mediating extracellular stimuli to intracellular signalling pathways. Integrins are composed of an $\alpha$ and $\beta$ subunit, giving rise to a large number of different integrin molecules that respond to and interact with specific ligands. The heterogeneity in integrin molecules and their ligands is also reflected in the diverse biological functions of these molecules, including cell cycle regulation, modulation of the cell shape, cell motility, invasion and metastasis.

The crosstalk between c-Met and integrins is complex and involves a reciprocal regulation that can be ligand-dependent or -independent and signalling to similar downstream signalling molecules, leading to enhanced activation of those molecules and a c-Met-dependent transcriptional regulation of integrin expression [128].

The best-studied integrin receptor in relation to c-Met signalling is probably the $\alpha 6 \beta 4$ receptor, which binds laminin. Although both receptors can individually promote invasion [129], several reports suggest an association between this integrin and c-Met, which amplifies the signalling of both receptors [71,77-80]. Binding between c-Met and $\alpha 6 \beta 4$ promoted phosphorylation of the $\beta 4$ integrin unit, enabling a subsequent activation of Shc and PI3K. c-Met activation occurred independent of integrin binding to laminin, as a truncated variant of $\beta 4$ integrin unable to bind the ligand laminin still retained the ability to trigger invasion of cells in a HGF- and c-Met-dependent manner [62,77]. The $\beta 4$ integrin/c-Met interaction can also impinge on other c-Met functions, as demonstrated in endothelial cells, in which HGF induced the formation of a $\beta 4$ integrin/c-Met/sphingosine 1-phosphate receptor 1 (S1PR1) complex that was localized at CEMs and promoted vascular integrity [80] or in prostate tumour progenitor cells that underwent self-renewal [79].

c-Met was found to associate with other integrins, including the $\beta 1$ integrins, and, thereby, promoted an invasive program or induced kidney development [81-85]. Mitra et al. reported that in epithelial cells, fibronectin promoted the association between $\alpha 5 \beta 1$ integrin and c-Met, leading to c-Met phosphorylation and increased Src and FAK activation [82]. Interestingly, in agreement with previous studies that reported c-Met activation upon cell adhesion in the absence of ligand, $\alpha 5 \beta 1$ integrin-mediated c-Met signalling was independent of the presence of HGF [82,130].

Together, these data demonstrate that a variety of integrins and, by implication, cell adhesion can positively influence c-Met signalling. The interaction between other RTKs and integrins has been studied in more detail and revealed more details on how integrins and the extracellular matrix can regulate RTK function [131]. For example, matrix attachment can exert inhibitory functions on EGFR [132], and EGFR signalling seems critically dependent on EGFR co-recycling with the $\alpha 5 \beta 1$ integrin in an RCP-dependent manner [133]. Given that RCP can promote recycling of c-Met [51], it is likely that $\alpha 5 \beta 1$ integrin can also promote c-Met recycling. Further research is needed to elucidate the precise functional and mechanistic details underlying the integrin and c-Met interaction and their interplay. 


\subsection{Tetraspanins}

c-Met was also found to interact with members of the tetraspanin superfamily of membrane-spanning proteins. These molecules are known for their tight association with integrins and can modulate their function, possibly through compartmentalization of integrins [134]. It is therefore not surprising that some tetraspanin molecules can impinge on the c-Met/integrin interactions and regulate c-Met signalling. Klosek et al. first showed in human salivary gland cells that CD151 associates with c-Met and $\alpha 3$ or $\alpha 6$ integrin subunits, enhancing HGF/c-Met signalling to promote cell migration and proliferation [69]. Similarly, they found that the CD151 interaction with c-Met in MDA-MB-231 breast cancer cells triggered Akt activation, resulting in branching networks in Matrigel [70]. In GTL16 cells, Franco et al. revealed that CD151 associates with the c-Met receptor to drive $\beta 4$ integrin phosphorylation and facilitated the coupling between c-Met and Gab1-Grb2 to promote MAPK phosphorylation and tumour growth [71].

Conversely, many publications have demonstrated an inhibitory role for the tetraspanin CD82 in c-Met signalling [72-76]. CD82, possibly in combination with gangliosides [73,75], prevents c-Met phosphorylation upon HGF activation, exposure to the extracellular matrix ligands or EGFR transactivation [72,74,76]. This leads to impaired binding of c-Met to Gab1/Grb2 [76], decreased Ras or Src activation [72,74] and a subsequent decrease in migration, invasion or differentiation. As the tetraspanins consist of a large family of proteins that can interact with different integrins, it is likely that other tetraspanin proteins will contribute to c-Met signalling. One likely candidate could be the tetraspanin, CD9, which was shown to contribute to cell migration, to facilitate FAK phosphorylation and to interact with EGFR [135,136].

\subsection{Other RTKS}

As signalling from RTKs is often amplified in human cancers, many therapeutics aim to target and inhibit RTKs. Using such inhibitors, it has become obvious that c-Met plays an important role in activating or potentiating the response of other RTKs or vice versa and that amplification or activation of c-Met contributes to chemoresistance. RTKs comprise a family of 58 proteins [137] and the closest related family member of c-Met that c-Met has been shown to associate with is RON [86]. Ligand-dependent hetero-dimerization induced specific transphosphorylation of the respective catalytic and docking sites on either RTK, leading to fully activated downstream signalling pathways and increased colony formation of NIH3T3 cells [86].

A large number of publications describe EGFR and c-Met crosstalk in which either RTK can promote the function of the other RTK and/or converge at similar hubs in their signalling pathways. One of the first reports by Jo et al. analysing this crosstalk revealed that in epithelial cancer cells, but not in "normal" liver cells, c-Met was constitutively phosphorylated upon TGF $\alpha$ and EGF exposure in the absence of HGF [87]. The authors proposed that in tumour cells, TGF $\alpha$-mediated EGFR activation induces EGFR/c-Met interaction, detectable as co-immunoprecipitation and resulting in increased c-Met phosphorylation and signalling [87]. A cooperation between c-Met and EGFR interaction is even more apparent from the large number of reports that study drug resistance after inhibition of either RTK. Cells treated with EGFR inhibitors can acquire resistance through c-Met activation or 
amplification [93,138]. As an example, Troiani et al. confirmed the findings of Jo et al. and, in addition, revealed that overexpression of TGF- $\alpha$ could confer resistance to EGFR inhibitors through enhancing the EGFR/c-Met interaction and c-Met phosphorylation [99]. EGFR inhibitors can block HGF-mediated proliferation and motility [88,89], and several studies have highlighted the mutual synergism of c-Met and EGFR in promoting drug resistance, leading to the activation of PI3K/Akt and Gab1 [91-93,98,139]. The cellular effect of combination therapy can however be context- and cell-dependent, as demonstrated by Zhang et al. using xenograft models. Where H1993-derived tumours reacted to combination therapy by promoting apoptosis and suppressing proliferation, H1373-derived tumours only responded with decreased proliferation [140]. Several groups have investigated the molecular mechanisms underlying the crosstalk between EGFR and c-Met, and it has become apparent that several partner proteins can affect EGFR-mediated phosphorylation of c-Met, including Src, MAPK and $\beta 1$ integrins [84,94,100,101]. Conversely, HGF stimulation could also induce EGFR phosphorylation [138,141], pointing out the reciprocal regulation of both receptors. Other molecules that have been implicated in the crosstalk include miR-27A, sprouty, the Wnt and the mTor signaling pathways, although the precise mechanisms underlying their role in the crosstalk are unknown [142,143]. EGFR was also found to promote c-Met oncogenic function via an alternative mechanism through promoting c-Met ecto-domain shedding, leading to enhanced wound healing $[95,96]$, a process that has previously been described to promote the oncogenic function of c-Met [144].

Similar reciprocal relationships were found between c-Met and the EGFR family members, Her2 and Her3 [91,97,102-105], IGFR [106] and RET [97]. Interestingly, Tanizaki et al. revealed differential functional consequences in a cell line that overexpresses c-Met upon heterodimerization between c-Met and RET, EGFR, Her2 or Her3 [97]. Loss of EGFR and Her3 resulted in a decrease in cell proliferation and survival; loss of RET decreased cell migration; and loss of Her2 decreased proliferation, survival and cell migration [97]. These results suggest some specificity in the functional outcome of c-Met partnerships with other RTKs. As c-Met is often amplified in human tumours and is a target for drug strategies, a more thorough understanding of the crosstalk between c-Met and other RTKs is necessary.

\section{6. c-Met and Others}

Other membrane spanning molecules that affect c-Met function or that are affected by c-Met interaction are mucins and death receptors. Mucins are transmembrane glycoproteins, and tumour-associated Muc1 has been shown to be important in activating signal transduction pathways to promote invasion, metastasis, proliferation and chemoresistance [145]. As opposed to this pro-tumourigenic role, in pancreatic and liver cancer cells, mucl interacting with c-Met was found to inhibit c-Met-dependent invasion and migration [111,113,114], possibly through enhanced c-Met turnover [113]. Muc20 similarly inhibited c-Met in Hek293 and CHO-K1 cells [114]. However, in breast cancer cells, Muc1 was shown to promote c-Met-driven migration and scattering through regulation of $c-M e t$ mRNA expression levels [112], suggesting that tissue conditional aspects determine the consequences of the relationship between Muc1 and c-Met.

Activation of RAF/MEK/ERK and the PI3K/PDK/Akt promotes proliferation and survival, while preventing apoptosis [146]. Via activation of these signalling routes, c-Met can inhibit apoptosis, 
but c-Met has also been shown to influence apoptosis through interaction with cell death receptors on the cell membrane. Through interacting with Fas, c-Met prevents Fas trimerization and recruitment of an active DISC complex and, therefore, acts as an antagonist for the Fas ligand (FasL) [107-109]. Activation of the c-Met receptor following HGF abrogated the c-Met/Fas interaction and promoted FasL or doxorubicin-induced apoptosis [107,147]. Fatty acids or anoikis also lead to c-Met dissociation from Fas and an increase in the sensitivity to apoptosis, suggesting that the external environment, possibly through the involvement of integrins, could modulate c-Met's function on Fas $[108,109]$. Similarly to Fas, DR5 was also found to be inhibited upon c-Met interaction, preventing it from interacting with TRAIL and DISC association [110]. These reports are indicative of a direct role for the inactive c-Met receptor in preventing apoptosis.

\section{Conclusions and Future Perspectives}

It is clear that c-Met function is dynamically regulated and modulated by its localization, through protein modifications and interaction with a large variety of signalling molecules, co-receptors and other membrane molecules. These interactions can greatly affect the way c-Met reacts to its ligand, HGF, but can also change the way in which c-Met will react to drug strategies that are designed to inhibit c-Met function. Inhibiting c-Met alone might not be enough to fully inhibit the c-Met signalling cascade, as other RTKs might take over this function or RTKs or other cell membrane receptors simply transactivate c-Met in a ligand-independent manner. Inhibiting multiple cell surface molecules (e.g., multiple RTKs), including c-Met, might therefore have some therapeutic potential. Trials in which c-Met and the EGFR are targeted simultaneously reveal that some NSCLC (non-small cell lung cancer) patients responded with an increased progression-free survival and overall survival, although in some patients, dependent on the molecular alterations in their genome, worse outcomes were noted [148,149]. Other combinations of RTK inhibitors for NSCLC are also being explored (summarized in [150]), as well as targeting downstream convergent signaling routes of RTKs [151]. Given that c-Met interacts with other cell surface molecules and not just other RTKs, it might also be worthwhile to investigate combination therapies in which other cell surface molecules, e.g., integrins (for which some approved drugs exist [152]), are co-targeted together with c-Met. This is also interesting in the context of RTK crosstalk, as the interaction between c-Met and integrin $\beta 1$ was demonstrated to mediate EGFR inhibitor resistance [84]. Alternatively, it might be worthwhile to target common features of cell surface molecules, such as recycling or endocytosis. We have previously identified that recycling of EGFR, c-Met and integrin $\alpha 5 \beta 1$ was enhanced in the oncogenic setting of p53 mutations by RCP [51], leading to enhanced signalling towards Akt and ERK1/2 [51,53]. Although a better mechanistic understanding of the mutant p53 functions on RCP is required, it will be interesting to explore RCP inhibition as a means to inhibit recycling of various receptors, including c-Met, integrins and EGFR, simultaneously.

In conclusion, a better understanding of the c-Met interactors and the consequences of these interactions on c-Met signaling will help in the design of novel therapeutic strategies and in understanding the shortcomings of current strategies, including drug resistance. 


\section{Acknowledgments}

Patricia A. J. Muller is funded by a Sir Henry Dale fellowship from the Royal Society/Wellcome Trust.

\section{Conflicts of Interest}

The authors declare no conflict of interest.

\section{References}

1. Christofori, G. New signals from the invasive front. Nature 2006, 441, 444-450.

2. Birchmeier, C.; Birchmeier, W.; Gherardi, E.; vande Woude, G.F. Met, metastasis, motility and more. Nat. Rev. Mol. Cell Biol. 2003, 4, 915-925.

3. Park, M.; Dean, M.; Kaul, K.; Braun, M.J.; Gonda, M.A.; vande Woude, G. Sequence of met protooncogene CDNA has features characteristic of the tyrosine kinase family of growth-factor receptors. Proc. Natl. Acad. Sci. USA 1987, 84, 6379-6383.

4. Stoker, M.; Gherardi, E.; Perryman, M.; Gray, J. Scatter factor is a fibroblast-derived modulator of epithelial cell mobility. Nature 1987, 327, 239-242.

5. Hartmann, G.; Weidner, K.M.; Schwarz, H.; Birchmeier, W. The motility signal of scatter factor/hepatocyte growth factor mediated through the receptor tyrosine kinase met requires intracellular action of ras. J. Biol. Chem. 1994, 269, 21936-21939.

6. Khwaja, A.; Lehmann, K.; Marte, B.M.; Downward, J. Phosphoinositide 3-kinase induces scattering and tubulogenesis in epithelial cells through a novel pathway. J. Biol. Chem. 1998, 273, 18793-18801.

7. Maroun, C.R.; Holgado-Madruga, M.; Royal, I.; Naujokas, M.A.; Fournier, T.M.; Wong, A.J.; Park, M. The gab1 ph domain is required for localization of gab1 at sites of cell-cell contact and epithelial morphogenesis downstream from the met receptor tyrosine kinase. Mol. Cell. Biol. 1999, 19, 1784-1799.

8. Schaeper, U.; Gehring, N.H.; Fuchs, K.P.; Sachs, M.; Kempkes, B.; Birchmeier, W. Coupling of gab1 to c-Met, Grb2, and Shp2 mediates biological responses. J. Cell Biol. 2000, 149, 1419-1432.

9. Weidner, K.M.; di Cesare, S.; Sachs, M.; Brinkmann, V.; Behrens, J.; Birchmeier, W. Interaction between gab1 and the c-Met receptor tyrosine kinase is responsible for epithelial morphogenesis. Nature 1996, 384, 173-176.

10. Lamorte, L.; Kamikura, D.M.; Park, M. A switch from p130Cas/Crk to Gab1/Crk signaling correlates with anchorage independent growth and jnk activation in cells transformed by the Met receptor oncoprotein. Oncogene 2000, 19, 5973-5981.

11. Giordano, S.; Ponzetto, C.; di Renzo, M.F.; Cooper, C.S.; Comoglio, P.M. Tyrosine kinase receptor indistinguishable from the c-Met protein. Nature 1989, 339, 155-156.

12. Stamos, J.; Lazarus, R.A.; Yao, X.; Kirchhofer, D.; Wiesmann, C. Crystal structure of the HGF beta-chain in complex with the sema domain of the met receptor. EMBO J. 2004, 23, 2325-2335.

13. Ponzetto, C.; Bardelli, A.; Zhen, Z.; Maina, F.; dalla Zonca, P.; Giordano, S.; Graziani, A.; Panayotou, G.; Comoglio, P.M. A multifunctional docking site mediates signaling and transformation by the hepatocyte growth factor/scatter factor receptor family. Cell 1994, 77, 261-271. 
14. Gual, P.; Giordano, S.; Williams, T.A.; Rocchi, S.; van Obberghen, E.; Comoglio, P.M. Sustained recruitment of phospholipase C-gamma to Gab1 is required for hgf-induced branching tubulogenesis. Oncogene 2000, 19, 1509-1518.

15. Maroun, C.R.; Naujokas, M.A.; Holgado-Madruga, M.; Wong, A.J.; Park, M. The tyrosine phosphatase Shp-2 is required for sustained activation of extracellular signal-regulated kinase and epithelial morphogenesis downstream from the met receptor tyrosine kinase. Mol. Cell. Biol. 2000, 20, 8513-8525.

16. Montagner, A.; Yart, A.; Dance, M.; Perret, B.; Salles, J.P.; Raynal, P. A novel role for Gab1 and Shp2 in epidermal growth factor-induced ras activation. J. Biol. Chem. 2005, 280, 5350-5360.

17. Sachs, M.; Brohmann, H.; Zechner, D.; Muller, T.; Hulsken, J.; Walther, I.; Schaeper, U.; Birchmeier, C.; Birchmeier, W. Essential role of Gab1 for signaling by the c-Met receptor in vivo. J. Cell Biol. 2000, 150, 1375-1384.

18. Lock, L.S.; Royal, I.; Naujokas, M.A.; Park, M. Identification of an atypical Grb2 carboxyl-terminal Sh3 domain binding site in gab docking proteins reveals Grb2-dependent and -independent recruitment of Gab1 to receptor tyrosine kinases. J. Biol. Chem. 2000, 275, 31536-31545.

19. Machide, M.; Hashigasako, A.; Matsumoto, K.; Nakamura, T. Contact inhibition of hepatocyte growth regulated by functional association of the c-Met/hepatocyte growth factor receptor and lar protein-tyrosine phosphatase. J. Biol. Chem. 2006, 281, 8765-8772.

20. Palka, H.L.; Park, M.; Tonks, N.K. Hepatocyte growth factor receptor tyrosine kinase Met is a substrate of the receptor protein-tyrosine phosphatase Dep-1. J. Biol. Chem. 2003, 278, 5728-5735.

21. Sangwan, V.; Paliouras, G.N.; Abella, J.V.; Dube, N.; Monast, A.; Tremblay, M.L.; Park, M. Regulation of the met receptor-tyrosine kinase by the protein-tyrosine phosphatase $1 \mathrm{~B}$ and T-cell phosphatase. J. Biol. Chem. 2008, 283, 34374-34383.

22. Lai, A.Z.; Abella, J.V.; Park, M. Crosstalk in met receptor oncogenesis. Trends Cell Biol. 2009, 19, 542-551.

23. Trusolino, L.; Comoglio, P.M. Scatter-factor and semaphorin receptors: Cell signalling for invasive growth. Nat. Rev. Cancer 2002, 2, 289-300.

24. Trusolino, L.; Bertotti, A.; Comoglio, P.M. Met signalling: Principles and functions in development, organ regeneration and cancer. Nat. Rev. Mol. Cell Biol. 2010, 11, 834-848.

25. Pelicci, G.; Giordano, S.; Zhen, Z.; Salcini, A.E.; Lanfrancone, L.; Bardelli, A.; Panayotou, G.; Waterfield, M.D.; Ponzetto, C.; Pelicci, P.G.; et al. The motogenic and mitogenic responses to hgf are amplified by the shc adaptor protein. Oncogene 1995, 10, 1631-1638.

26. Paumelle, R.; Tulasne, D.; Kherrouche, Z.; Plaza, S.; Leroy, C.; Reveneau, S.; vanden Bunder, B.; Fafeur, V. Hepatocyte growth factor/scatter factor activates the ets1 transcription factor by a ras-raf-mek-erk signaling pathway. Oncogene 2002, 21, 2309-2319.

27. Garcia-Guzman, M.; Dolfi, F.; Zeh, K.; Vuori, K. Met-induced jnk activation is mediated by the adapter protein crk and correlates with the Gab1-Crk signaling complex formation. Oncogene 1999, 18, 7775-7786.

28. Fan, S.; Ma, Y.X.; Gao, M.; Yuan, R.Q.; Meng, Q.; Goldberg, I.D.; Rosen, E.M. The multisubstrate adapter gab1 regulates hepatocyte growth factor (scatter factor)-c-Met signaling for cell survival and DNA repair. Mol. Cell. Biol. 2001, 21, 4968-4984. 
29. Xiao, G.H.; Jeffers, M.; Bellacosa, A.; Mitsuuchi, Y.; vande Woude, G.F.; Testa, J.R. Anti-apoptotic signaling by hepatocyte growth factor/met via the phosphatidylinositol 3-kinase/akt and mitogen-activated protein kinase pathways. Proc. Natl. Acad. Sci. USA 2001, 98, 247-252.

30. Sipeki, S.; Bander, E.; Buday, L.; Farkas, G.; Bacsy, E.; Ways, D.K.; Farago, A. Phosphatidylinositol 3-kinase contributes to Erk1/Erk2 map kinase activation associated with hepatocyte growth factor-induced cell scattering. Cell. Signal. 1999, 11, 885-890.

31. Boccaccio, C.; Ando, M.; Tamagnone, L.; Bardelli, A.; Michieli, P.; Battistini, C.; Comoglio, P.M. Induction of epithelial tubules by growth factor hgf depends on the stat pathway. Nature 1998, 391, 285-288.

32. Zhang, Y.W.; Wang, L.M.; Jove, R.; vande Woude, G.F. Requirement of Stat3 signaling for HGF/SF-Met mediated tumorigenesis. Oncogene 2002, 21, 217-226.

33. Di Fiore, P.P.; Gill, G.N. Endocytosis and mitogenic signaling. Curr. Opin. Cell Biol. 1999, 11, 483-488.

34. Hammond, D.E.; Urbe, S.; vande Woude, G.F.; Clague, M.J. Down-regulation of Met, the receptor for hepatocyte growth factor. Oncogene 2001, 20, 2761-2770.

35. Petrelli, A.; Gilestro, G.F.; Lanzardo, S.; Comoglio, P.M.; Migone, N.; Giordano, S. The endophilin-CIN85-CBL complex mediates ligand-dependent downregulation of c-Met. Nature 2002, 416, 187-190.

36. Korhan, P.; Erdal, E.; Kandemis, E.; Cokakli, M.; Nart, D.; Yilmaz, F.; Can, A.; Atabey, N. Reciprocal activating crosstalk between c-Met and caveolin 1 promotes invasive phenotype in hepatocellular carcinoma. PLoS One 2014, 9, e105278.

37. Li, N.; Lorinczi, M.; Ireton, K.; Elferink, L.A. Specific Grb2-mediated interactions regulate clathrin-dependent endocytosis of the c-Met-tyrosine kinase. J. Biol. Chem. 2007, 282, 16764-16775.

38. Abella, J.V.; Parachoniak, C.A.; Sangwan, V.; Park, M. Dorsal ruffle microdomains potentiate met receptor tyrosine kinase signaling and down-regulation. J. Biol. Chem. 2010, 285, 24956-24967.

39. Ogi, S.; Fujita, H.; Kashihara, M.; Yamamoto, C.; Sonoda, K.; Okamoto, I.; Nakagawa, K.; Ohdo, S.; Tanaka, Y.; Kuwano, M.; et al. Sorting nexin 2-mediated membrane trafficking of c-Met contributes to sensitivity of molecular-targeted drugs. Cancer Sci. 2013, 104, 573-583.

40. Hasenauer, S.; Malinger, D.; Koschut, D.; Pace, G.; Matzke, A.; von Au, A.; Orian-Rousseau, V. Internalization of met requires the co-receptor CD44V6 and its link to erm proteins. PLoS One 2013, 8, e62357.

41. Jeffers, M.; Taylor, G.A.; Weidner, K.M.; Omura, S.; vande Woude, G.F. Degradation of the Met tyrosine kinase receptor by the ubiquitin-proteasome pathway. Mol. Cell. Biol. 1997, 17, 799-808.

42. Sangwan, V.; Abella, J.; Lai, A.; Bertos, N.; Stuible, M.; Tremblay, M.L.; Park, M. Protein-tyrosine phosphatase 1B modulates early endosome fusion and trafficking of met and epidermal growth factor receptors. J. Biol. Chem. 2011, 286, 45000-45013.

43. Miaczynska, M.; Pelkmans, L.; Zerial, M. Not just a sink: Endosomes in control of signal transduction. Curr. Opin. Cell Biol. 2004, 16, 400-406.

44. Kermorgant, S.; Parker, P.J. Receptor trafficking controls weak signal delivery: A strategy used by c-met for stat3 nuclear accumulation. J. Cell Biol. 2008, 182, 855-863. 
45. Menard, L.; Parker, P.J.; Kermorgant, S. Receptor tyrosine kinase c-Met controls the cytoskeleton from different endosomes via different pathways. Nat. Commun. 2014, 5, 3907.

46. Kermorgant, S.; Zicha, D.; Parker, P.J. Pkc controls hgf-dependent c-Met traffic, signalling and cell migration. EMBO J. 2004, 23, 3721-3734.

47. Masui, H.; Castro, L.; Mendelsohn, J. Consumption of EGF by A431 cells: Evidence for receptor recycling. J. Cell Biol. 1993, 120, 85-93.

48. Joffre, C.; Barrow, R.; Menard, L.; Calleja, V.; Hart, I.R.; Kermorgant, S. A direct role for Met endocytosis in tumorigenesis. Nat. Cell Biol. 2011, 13, 827-837.

49. Hammond, D.E.; Carter, S.; McCullough, J.; Urbe, S.; vande Woude, G.; Clague, M.J. Endosomal dynamics of met determine signaling output. Mol. Biol. Cell 2003, 14, 1346-1354.

50. Muharram, G.; Sahgal, P.; Korpela, T.; de Franceschi, N.; Kaukonen, R.; Clark, K.; Tulasne, D.; Carpen, O.; Ivaska, J. Tensin-4-dependent met stabilization is essential for survival and proliferation in carcinoma cells. Dev. Cell 2014, 29, 421-436.

51. Muller, P.A.; Trinidad, A.G.; Timpson, P.; Morton, J.P.; Zanivan, S.; van den Berghe, P.V.; Nixon, C.; Karim, S.A.; Caswell, P.T.; Noll, J.E.; et al. Mutant p53 enhances met trafficking and signalling to drive cell scattering and invasion. Oncogene 2013, 32, 1252-1265.

52. Parachoniak, C.A.; Luo, Y.; Abella, J.V.; Keen, J.H.; Park, M. Gga3 functions as a switch to promote met receptor recycling, essential for sustained erk and cell migration. Dev. Cell 2011, 20, 751-763.

53. Muller, P.A.; Caswell, P.T.; Doyle, B.; Iwanicki, M.P.; Tan, E.H.; Karim, S.; Lukashchuk, N.; Gillespie, D.A.; Ludwig, R.L.; Gosselin, P.; et al. Mutant p53 drives invasion by promoting integrin recycling. Cell 2009, 139, 1327-1341.

54. Conrotto, P.; Valdembri, D.; Corso, S.; Serini, G.; Tamagnone, L.; Comoglio, P.M.; Bussolino, F.; Giordano, S. Sema4d induces angiogenesis through met recruitment by plexin b1. Blood 2005, 105, 4321-4329.

55. Conrotto, P.; Corso, S.; Gamberini, S.; Comoglio, P.M.; Giordano, S. Interplay between scatter factor receptors and b plexins controls invasive growth. Oncogene 2004, 23, 5131-5137.

56. Giordano, S.; Corso, S.; Conrotto, P.; Artigiani, S.; Gilestro, G.; Barberis, D.; Tamagnone, L.; Comoglio, P.M. The semaphorin 4d receptor controls invasive growth by coupling with Met. Nat. Cell Biol. 2002, 4, 720-724.

57. Soong, J.; Scott, G. Plexin B1 inhibits met through direct association and regulates SHP2 expression in melanocytes. J. Cell Sci. 2013, 126, 688-695.

58. Stevens, L.; McClelland, L.; Fricke, A.; Williamson, M.; Kuo, I.; Scott, G. Plexin b1 suppresses c-Met in melanoma: A role for plexin b1 as a tumor-suppressor protein through regulation of c-Met. J. Investig. Dermatol. 2010, 130, 1636-1645.

59. Sun, T.; Krishnan, R.; Swiercz, J.M. Grb2 mediates semaphorin-4D-dependent rhoa inactivation. J. Cell Sci. 2012, 125, 3557-3567.

60. Swiercz, J.M.; Worzfeld, T.; Offermanns, S. Erbb-2 and met reciprocally regulate cellular signaling via plexin-b1. J. Biol. Chem. 2008, 283, 1893-1901.

61. Artigiani, S.; Conrotto, P.; Fazzari, P.; Gilestro, G.F.; Barberis, D.; Giordano, S.; Comoglio, P.M.; Tamagnone, L. Plexin-B3 is a functional receptor for semaphorin 5A. EMBO Rep. 2004, 5, $710-714$. 
62. Ghatak, S.; Hascall, V.C.; Markwald, R.R.; Misra, S. Stromal hyaluronan interaction with epithelial cd44 variants promotes prostate cancer invasiveness by augmenting expression and function of hepatocyte growth factor and androgen receptor. J. Biol. Chem. 2010, 285, 19821-19832.

63. Damm, S.; Koefinger, P.; Stefan, M.; Wels, C.; Mehes, G.; Richtig, E.; Kerl, H.; Otte, M.; Schaider, H. HGF-promoted motility in primary human melanocytes depends on CD44V6 regulated via NF-kappaB, EGR-1, and C/EBP-beta. J. Investig. Dermatol. 2010, 130, 1893-1903.

64. Orian-Rousseau, V.; Chen, L.; Sleeman, J.P.; Herrlich, P.; Ponta, H. CD44 is required for two consecutive steps in HGF/c-Met signaling. Genes Dev. 2002, 16, 3074-3086.

65. Orian-Rousseau, V.; Morrison, H.; Matzke, A.; Kastilan, T.; Pace, G.; Herrlich, P.; Ponta, H. Hepatocyte growth factor-induced ras activation requires erm proteins linked to both CD44V6 and F-actin. Mol. Biol. Cell 2007, 18, 76-83.

66. Ghatak, S.; Bogatkevich, G.S.; Atnelishvili, I.; Akter, T.; Feghali-Bostwick, C.; Hoffman, S.; Fresco, V.M.; Fuchs, J.C.; Visconti, R.P.; Markwald, R.R.; et al. Overexpression of c-Met and CD44V6 receptors contributes to autocrine tgf-betal signaling in interstitial lung disease. J. Biol. Chem. 2014, 289, 7856-7872.

67. Gordin, M.; Tesio, M.; Cohen, S.; Gore, Y.; Lantner, F.; Leng, L.; Bucala, R.; Shachar, I. c-Met and its ligand hepatocyte growth factor/scatter factor regulate mature b cell survival in a pathway induced by cd74. J. Immunol. 2010, 185, 2020-2031.

68. Singleton, P.A.; Salgia, R.; Moreno-Vinasco, L.; Moitra, J.; Sammani, S.; Mirzapoiazova, T.; Garcia, J.G. CD44 regulates hepatocyte growth factor-mediated vascular integrity. Role of c-Met, tiam1/rac1, dynamin 2, and cortactin. J. Biol. Chem. 2007, 282, 30643-30657.

69. Klosek, S.K.; Nakashiro, K.; Hara, S.; Shintani, S.; Hasegawa, H.; Hamakawa, H. CD151 forms a functional complex with c-Met in human salivary gland cancer cells. Biochem. Biophys. Res. Commun. 2005, 336, 408-416.

70. Klosek, S.K.; Nakashiro, K.; Hara, S.; Goda, H.; Hasegawa, H.; Hamakawa, H. CD151 regulates HGF-stimulated morphogenesis of human breast cancer cells. Biochem. Biophys. Res. Commun. 2009, 379, 1097-1100.

71. Franco, M.; Muratori, C.; Corso, S.; Tenaglia, E.; Bertotti, A.; Capparuccia, L.; Trusolino, L.; Comoglio, P.M.; Tamagnone, L. The tetraspanin CD151 is required for Met-dependent signaling and tumor cell growth. J. Biol. Chem. 2010, 285, 38756-38764.

72. Sridhar, S.C.; Miranti, C.K. Tetraspanin KAI1/CD82 suppresses invasion by inhibiting integrin-dependent crosstalk with c-Met receptor and src kinases. Oncogene 2006, 25, 2367-2378.

73. Li, Y.; Huang, X.; Zhang, J.; Li, Y.; Ma, K. Synergistic inhibition of cell migration by tetraspanin cd82 and gangliosides occurs via the egfr or cmet-activated pl3k/akt signalling pathway. Int. J. Biochem. Cell Biol. 2013, 45, 2349-2358.

74. Mela, A.; Goldman, J.E. Cd82 blocks cmet activation and overcomes hepatocyte growth factor effects on oligodendrocyte precursor differentiation. J. Neurosci. 2013, 33, 7952-7960.

75. Todeschini, A.R.; dos Santos, J.N.; Handa, K.; Hakomori, S.I. Ganglioside GM2-tetraspanin CD82 complex inhibits Met and its cross-talk with integrins, providing a basis for control of cell motility through glycosynapse. J. Biol. Chem. 2007, 282, 8123-8133. 
76. Takahashi, M.; Sugiura, T.; Abe, M.; Ishii, K.; Shirasuna, K. Regulation of c-Met signaling by the tetraspanin KAI-1/CD82 affects cancer cell migration. Int. J. Cancer 2007, 121, 1919-1929.

77. Trusolino, L.; Bertotti, A.; Comoglio, P.M. A signaling adapter function for alpha6beta4 integrin in the control of HGF-dependent invasive growth. Cell 2001, 107, 643-654.

78. Bertotti, A.; Comoglio, P.M.; Trusolino, L. Beta4 integrin is a transforming molecule that unleashes met tyrosine kinase tumorigenesis. Cancer Res. 2005, 65, 10674-10679.

79. Yoshioka, T.; Otero, J.; Chen, Y.; Kim, Y.M.; Koutcher, J.A.; Satagopan, J.; Reuter, V.; Carver, B.; de Stanchina, E.; Enomoto, K.; et al. Beta4 integrin signaling induces expansion of prostate tumor progenitors. J. Clin. Investig. 2013, 123, 682-699.

80. Ephstein, Y.; Singleton, P.A.; Chen, W.; Wang, L.; Salgia, R.; Kanteti, P.; Dudek, S.M.; Garcia, J.G.; Jacobson, J.R. Critical role of S1PR1 and integrin beta4 in HGF/c-Met-mediated increases in vascular integrity. J. Biol. Chem. 2013, 288, 2191-2200.

81. Rahman, S.; Patel, Y.; Murray, J.; Patel, K.V.; Sumathipala, R.; Sobel, M.; Wijelath, E.S. Novel hepatocyte growth factor (HGF) binding domains on fibronectin and vitronectin coordinate a distinct and amplified met-integrin induced signalling pathway in endothelial cells. BMC Cell Biol. 2005, 6, 8 .

82. Mitra, A.K.; Sawada, K.; Tiwari, P.; Mui, K.; Gwin, K.; Lengyel, E. Ligand-independent activation of c-Met by fibronectin and alpha5beta1-integrin regulates ovarian cancer invasion and metastasis. Oncogene 2011, 30, 1566-1576.

83. Liu, Y.; Chattopadhyay, N.; Qin, S.; Szekeres, C.; Vasylyeva, T.; Mahoney, Z.X.; Taglienti, M.; Bates, C.M.; Chapman, H.A.; Miner, J.H.; et al. Coordinate integrin and c-Met signaling regulate wnt gene expression during epithelial morphogenesis. Development 2009, 136, 843-853.

84. Ju, L.; Zhou, C. Association of integrin betal and c-Met in mediating EGFR TKI gefitinib resistance in non-small cell lung cancer. Cancer Cell Int. 2013, 13, 15.

85. McCall-Culbreath, K.D.; Li, Z.; Zutter, M.M. Crosstalk between the alpha2beta1 integrin and c-Met/HGF-R regulates innate immunity. Blood 2008, 111, 3562-3570.

86. Follenzi, A.; Bakovic, S.; Gual, P.; Stella, M.C.; Longati, P.; Comoglio, P.M. Cross-talk between the proto-oncogenes met and ron. Oncogene 2000, 19, 3041-3049.

87. Jo, M.; Stolz, D.B.; Esplen, J.E.; Dorko, K.; Michalopoulos, G.K.; Strom, S.C. Cross-talk between epidermal growth factor receptor and c-met signal pathways in transformed cells. J. Biol. Chem. 2000, 275, 8806-8811.

88. Bonine-Summers, A.R.; Aakre, M.E.; Brown, K.A.; Arteaga, C.L.; Pietenpol, J.A.; Moses, H.L.; Cheng, N. Epidermal growth factor receptor plays a significant role in hepatocyte growth factor mediated biological responses in mammary epithelial cells. Cancer Biol. Ther. 2007, 6, 561-570.

89. Zhang, Y.W.; Staal, B.; Essenburg, C.; Su, Y.; Kang, L.; West, R.; Kaufman, D.; Dekoning, T.; Eagleson, B.; Buchanan, S.G.; et al. Met kinase inhibitor SGX523 synergizes with epidermal growth factor receptor inhibitor erlotinib in a hepatocyte growth factor-dependent fashion to suppress carcinoma growth. Cancer Res. 2010, 70, 6880-6890.

90. Huang, P.H.; Mukasa, A.; Bonavia, R.; Flynn, R.A.; Brewer, Z.E.; Cavenee, W.K.; Furnari, F.B.; White, F.M. Quantitative analysis of egfrviii cellular signaling networks reveals a combinatorial therapeutic strategy for glioblastoma. Proc. Natl. Acad. Sci. USA 2007, 104, 12867-12872. 
91. Bachleitner-Hofmann, T.; Sun, M.Y.; Chen, C.T.; Tang, L.; Song, L.; Zeng, Z.; Shah, M.; Christensen, J.G.; Rosen, N.; Solit, D.B.; et al. Her kinase activation confers resistance to met tyrosine kinase inhibition in Met oncogene-addicted gastric cancer cells. Mol. Cancer Ther. 2008, 7, 3499-3508.

92. Turke, A.B.; Zejnullahu, K.; Wu, Y.L.; Song, Y.; Dias-Santagata, D.; Lifshits, E.; Toschi, L.; Rogers, A.; Mok, T.; Sequist, L.; et al. Preexistence and clonal selection of met amplification in EGFR mutant nsclc. Cancer Cell 2010, 17, 77-88.

93. Yano, S.; Wang, W.; Li, Q.; Matsumoto, K.; Sakurama, H.; Nakamura, T.; Ogino, H.; Kakiuchi, S.; Hanibuchi, M.; Nishioka, Y.; et al. Hepatocyte growth factor induces gefitinib resistance of lung adenocarcinoma with epidermal growth factor receptor-activating mutations. Cancer Res. 2008, 68, 9479-9487.

94. Yamamoto, N.; Mammadova, G.; Song, R.X.; Fukami, Y.; Sato, K. Tyrosine phosphorylation of p145Met mediated by egfr and src is required for serum-independent survival of human bladder carcinoma cells. J. Cell Sci. 2006, 119, 4623-4633.

95. Xu, K.P.; Yu, F.S. Cross talk between c-met and epidermal growth factor receptor during retinal pigment epithelial wound healing. Investig. Ophthalmol. Vis. Sci. 2007, 48, 2242-2248.

96. Nath, D.; Williamson, N.J.; Jarvis, R.; Murphy, G. Shedding of c-Met is regulated by crosstalk between a G-protein coupled receptor and the egf receptor and is mediated by a timp-3 sensitive metalloproteinase. J. Cell Sci. 2001, 114, 1213-1220.

97. Tanizaki, J.; Okamoto, I.; Sakai, K.; Nakagawa, K. Differential roles of trans-phosphorylated EGFR, Her2, Her3, and Ret as heterodimerisation partners of met in lung cancer with Met amplification. Br. J. Cancer 2011, 105, 807-813.

98. Tang, Z.; Du, R.; Jiang, S.; Wu, C.; Barkauskas, D.S.; Richey, J.; Molter, J.; Lam, M.; Flask, C.; Gerson, S.; et al. Dual Met-EGFR combinatorial inhibition against t790m-EGFR-mediated erlotinib-resistant lung cancer. Br. J. Cancer 2008, 99, 911-922.

99. Troiani, T.; Martinelli, E.; Napolitano, S.; Vitagliano, D.; Ciuffreda, L.P.; Costantino, S.; Morgillo, F.; Capasso, A.; Sforza, V.; Nappi, A.; et al. Increased TGF-alpha as a mechanism of acquired resistance to the anti-EGFR inhibitor cetuximab through EGFR-Met interaction and activation of met signaling in colon cancer cells. Clin. Cancer Res. 2013, 19, 6751-6765.

100. Breindel, J.L.; Haskins, J.W.; Cowell, E.P.; Zhao, M.; Nguyen, D.X.; Stern, D.F. EGF receptor activates Met through mapk to enhance non-small cell lung carcinoma invasion and brain metastasis. Cancer Res. 2013, 73, 5053-5065.

101. Dulak, A.M.; Gubish, C.T.; Stabile, L.P.; Henry, C.; Siegfried, J.M. HGF-independent potentiation of EGFR action by c-Met. Oncogene 2011, 30, 3625-3635.

102. Shattuck, D.L.; Miller, J.K.; Carraway, K.L., 3rd; Sweeney, C. Met receptor contributes to trastuzumab resistance of Her2-overexpressing breast cancer cells. Cancer Res. 2008, 68, 1471-1477.

103. Khoury, H.; Naujokas, M.A.; Zuo, D.; Sangwan, V.; Frigault, M.M.; Petkiewicz, S.; Dankort, D.L.; Muller, W.J.; Park, M. HGF converts ERBB2/Neu epithelial morphogenesis to cell invasion. Mol. Biol. Cell 2005, 16, 550-561. 
104. Engelman, J.A.; Zejnullahu, K.; Mitsudomi, T.; Song, Y.; Hyland, C.; Park, J.O.; Lindeman, N.; Gale, C.M.; Zhao, X.; Christensen, J.; et al. Met amplification leads to gefitinib resistance in lung cancer by activating erbb3 signaling. Science 2007, 316, 1039-1043.

105. Guo, A.; Villen, J.; Kornhauser, J.; Lee, K.A.; Stokes, M.P.; Rikova, K.; Possemato, A.; Nardone, J.; Innocenti, G.; Wetzel, R.; et al. Signaling networks assembled by oncogenic EGFR and c-Met. Proc. Natl. Acad. Sci. USA 2008, 105, 692-697.

106. Bauer, T.W.; Somcio, R.J.; Fan, F.; Liu, W.; Johnson, M.; Lesslie, D.P.; Evans, D.B.; Gallick, G.E.; Ellis, L.M. Regulatory role of c-Met in insulin-like growth factor-I receptor-mediated migration and invasion of human pancreatic carcinoma cells. Mol. Cancer Ther. 2006, 5, 1676-1682.

107. Wang, X.; DeFrances, M.C.; Dai, Y.; Pediaditakis, P.; Johnson, C.; Bell, A.; Michalopoulos, G.K.; Zarnegar, R. A mechanism of cell survival: Sequestration of fas by the HGF receptor Met. Mol. Cell 2002, 9, 411-421.

108. Zou, C.; Ma, J.; Wang, X.; Guo, L.; Zhu, Z.; Stoops, J.; Eaker, A.E.; Johnson, C.J.; Strom, S.; Michalopoulos, G.K.; et al. Lack of Fas antagonism by met in human fatty liver disease. Nat. Med. 2007, 13, 1078-1085.

109. Smyth, L.A.; Brady, H.J. Cmet and Fas receptor interaction inhibits death-inducing signaling complex formation in endothelial cells. Hypertension 2005, 46, 100-106.

110. Du, W.; Uslar, L.; Sevala, S.; Shah, K. Targeting c-Met receptor overcomes trail-resistance in brain tumors. PLoS One 2014, 9, e95490.

111. Bozkaya, G.; Korhan, P.; Cokakli, M.; Erdal, E.; Sagol, O.; Karademir, S.; Korch, C.; Atabey, N. Cooperative interaction of mucl with the HGF/c-Met pathway during hepatocarcinogenesis. Mol. Cancer 2012, 11, 64.

112. Horm, T.M.; Bitler, B.G.; Broka, D.M.; Louderbough, J.M.; Schroeder, J.A. Muc1 drives c-Met-dependent migration and scattering. Mol. Cancer Res. 2012, 10, 1544-1554.

113. Singh, P.K.; Behrens, M.E.; Eggers, J.P.; Cerny, R.L.; Bailey, J.M.; Shanmugam, K.; Gendler, S.J.; Bennett, E.P.; Hollingsworth, M.A. Phosphorylation of mucl by met modulates interaction with p53 and mmp1 expression. J. Biol. Chem. 2008, 283, 26985-26995.

114. Higuchi, T.; Orita, T.; Katsuya, K.; Yamasaki, Y.; Akiyama, K.; Li, H.; Yamamoto, T.; Saito, Y.; Nakamura, M. Muc20 suppresses the hepatocyte growth factor-induced GRB2-Ras pathway by binding to a multifunctional docking site of met. Mol. Cell. Biol. 2004, 24, 7456-7468.

115. Zhang, S.; Zhau, H.E.; Osunkoya, A.O.; Iqbal, S.; Yang, X.; Fan, S.; Chen, Z.; Wang, R.; Marshall, F.F.; Chung, L.W.; et al. Vascular endothelial growth factor regulates myeloid cell leukemia-1 expression through neuropilin-1-dependent activation of c-Met signaling in human prostate cancer cells. Mol. Cancer 2010, 9, 9.

116. Olaku, V.; Matzke, A.; Mitchell, C.; Hasenauer, S.; Sakkaravarthi, A.; Pace, G.; Ponta, H.; Orian-Rousseau, V. c-Met recruits ICAM-1 as a coreceptor to compensate for the loss of CD44 in CD44 null mice. Mol. Biol. Cell 2011, 22, 2777-2786.

117. Tamagnone, L.; Artigiani, S.; Chen, H.; He, Z.; Ming, G.I.; Song, H.; Chedotal, A.; Winberg, M.L.; Goodman, C.S.; Poo, M.; et al. Plexins are a large family of receptors for transmembrane, secreted, and gpi-anchored semaphorins in vertebrates. Cell 1999, 99, 71-80. 
118. Driessens, M.H.; Hu, H.; Nobes, C.D.; Self, A.; Jordens, I.; Goodman, C.S.; Hall, A. Plexin-B semaphorin receptors interact directly with active rac and regulate the actin cytoskeleton by activating rho. Curr. Biol. 2001, 11, 339-344.

119. Tong, Y.; Chugha, P.; Hota, P.K.; Alviani, R.S.; Li, M.; Tempel, W.; Shen, L.; Park, H.W.; Buck, M. Binding of Rac1, Rnd1, and Rhod to a novel Rho GTPase interaction motif destabilizes dimerization of the plexin-B1 effector domain. J. Biol. Chem. 2007, 282, 37215-37224.

120. Ch'ng, E.S.; Kumanogoh, A. Roles of SEMA4D and plexin-B1 in tumor progression. Mol. Cancer 2010, 9, 251.

121. Damola, A.; Legendre, A.; Ball, S.; Masters, J.R.; Williamson, M. Function of mutant and wild-type plexinb1 in prostate cancer cells. Prostate 2013, 73, 1326-1335.

122. Weber, G.F.; Ashkar, S.; Glimcher, M.J.; Cantor, H. Receptor-ligand interaction between CD44 and osteopontin (ETA-1). Science 1996, 271, 509-512.

123. Van der Voort, R.; Taher, T.E.; Wielenga, V.J.; Spaargaren, M.; Prevo, R.; Smit, L.; David, G.; Hartmann, G.; Gherardi, E.; Pals, S.T. Heparan sulfate-modified CD44 promotes hepatocyte growth factor/scatter factor-induced signal transduction through the receptor tyrosine kinase c-Met. J. Biol. Chem. 1999, 274, 6499-6506.

124. Matzke, A.; Sargsyan, V.; Holtmann, B.; Aramuni, G.; Asan, E.; Sendtner, M.; Pace, G.; Howells, N.; Zhang, W.; Ponta, H.; et al. Haploinsufficiency of c-met in CD44 ${ }^{-1-}$ mice identifies a collaboration of CD44 and c-Met in vivo. Mol. Cell. Biol. 2007, 27, 8797-8806.

125. Crepaldi, T.; Gautreau, A.; Comoglio, P.M.; Louvard, D.; Arpin, M. Ezrin is an effector of hepatocyte growth factor-mediated migration and morphogenesis in epithelial cells. J. Cell Biol. 1997, 138, 423-434.

126. Hynes, R.O. Integrins: Versatility, modulation, and signaling in cell adhesion. Cell 1992, 69, 11-25.

127. Winograd-Katz, S.E.; Fassler, R.; Geiger, B.; Legate, K.R. The integrin adhesome: From genes and proteins to human disease. Nat. Rev. Mol. Cell Biol. 2014, 15, 273-288.

128. Chan, P.C.; Chen, S.Y.; Chen, C.H.; Chen, H.C. Crosstalk between hepatocyte growth factor and integrin signaling pathways. J. Biomed. Sci. 2006, 13, 215-223.

129. Chung, J.; Yoon, S.O.; Lipscomb, E.A.; Mercurio, A.M. The met receptor and alpha6beta4 integrin can function independently to promote carcinoma invasion. J. Biol. Chem. 2004, 279, 32287-32293.

130. Wang, R.; Kobayashi, R.; Bishop, J.M. Cellular adherence elicits ligand-independent activation of the met cell-surface receptor. Proc. Natl. Acad. Sci. USA 1996, 93, 8425-8430.

131. Ivaska, J.; Heino, J. Cooperation between integrins and growth factor receptors in signaling and endocytosis. Annu. Rev. Cell Dev. Biol. 2011, 27, 291-320.

132. Mattila, E.; Pellinen, T.; Nevo, J.; Vuoriluoto, K.; Arjonen, A.; Ivaska, J. Negative regulation of egfr signalling through integrin-alphalbeta1-mediated activation of protein tyrosine phosphatase tcptp. Nat. Cell Biol. 2005, 7, 78-85.

133. Caswell, P.T.; Chan, M.; Lindsay, A.J.; McCaffrey, M.W.; Boettiger, D.; Norman, J.C. RAB-coupling protein coordinates recycling of alpha5betal integrin and egfr1 to promote cell migration in 3D microenvironments. J. Cell Biol. 2008, 183, 143-155.

134. Bassani, S.; Cingolani, L.A. Tetraspanins: Interactions and interplay with integrins. Int. J. Biochem. Cell Biol. 2012, 44, 703-708. 
135. Chen, S.; Sun, Y.; Jin, Z.; Jing, X. Functional and biochemical studies of CD9 in fibrosarcoma cell line. Mol. Cell. Biochem. 2011, 350, 89-99.

136. Murayama, Y.; Shinomura, Y.; Oritani, K.; Miyagawa, J.; Yoshida, H.; Nishida, M.; Katsube, F.; Shiraga, M.; Miyazaki, T.; Nakamoto, T.; et al. The tetraspanin CD9 modulates epidermal growth factor receptor signaling in cancer cells. J. Cell. Physiol. 2008, 216, 135-143.

137. Robinson, D.R.; Wu, Y.M.; Lin, S.F. The protein tyrosine kinase family of the human genome. Oncogene 2000, 19, 5548-5557.

138. Mueller, K.L.; Hunter, L.A.; Ethier, S.P.; Boerner, J.L. Met and c-Src cooperate to compensate for loss of epidermal growth factor receptor kinase activity in breast cancer cells. Cancer Res. 2008, 68, 3314-3322.

139. Boccaccio, C.; Luraghi, P.; Comoglio, P.M. Met-mediated resistance to EGFR inhibitors: An old liaison rooted in colorectal cancer stem cells. Cancer Res. 2014, 74, 3647-3651.

140. Zhang, Y.W.; Staal, B.; Essenburg, C.; Lewis, S.; Kaufman, D.; vande Woude, G.F. Strengthening context-dependent anticancer effects on non-small cell lung carcinoma by inhibition of both Met and EGFR. Mol. Cancer Ther. 2013, 12, 1429-1441.

141. Reznik, T.E.; Sang, Y.; Ma, Y.; Abounader, R.; Rosen, E.M.; Xia, S.; Laterra, J. Transcription-dependent epidermal growth factor receptor activation by hepatocyte growth factor. Mol. Cancer Res. 2008, 6, 139-150.

142. Acunzo, M.; Romano, G.; Palmieri, D.; Lagana, A.; Garofalo, M.; Balatti, V.; Drusco, A.; Chiariello, M.; Nana-Sinkam, P.; Croce, C.M. Cross-talk between Met and EGFR in non-small cell lung cancer involves Mir-27a and sprouty2. Proc. Natl. Acad. Sci. USA 2013, 110, 8573-8578.

143. Fong, J.T.; Jacobs, R.J.; Moravec, D.N.; Uppada, S.B.; Botting, G.M.; Nlend, M.; Puri, N. Alternative signaling pathways as potential therapeutic targets for overcoming EGFR and c-Met inhibitor resistance in non-small cell lung cancer. PLoS One 2013, 8, e78398.

144. Merlin, S.; Pietronave, S.; Locarno, D.; Valente, G.; Follenzi, A.; Prat, M. Deletion of the ectodomain unleashes the transforming, invasive, and tumorigenic potential of the met oncogene. Cancer Sci. 2009, 100, 633-638.

145. Nath, S.; Mukherjee, P. Muc1: A multifaceted oncoprotein with a key role in cancer progression. Trends Mol. Med. 2014, 20, 332-342.

146. Chappell, W.H.; Steelman, L.S.; Long, J.M.; Kempf, R.C.; Abrams, S.L.; Franklin, R.A.; Basecke, J.; Stivala, F.; Donia, M.; Fagone, P.; et al. Ras/Raf/Mek/ERK and pi3k/pten/Akt/MTOR inhibitors: Rationale and importance to inhibiting these pathways in human health. Oncotarget 2011, 2 , 135-164.

147. Accordi, B.; Pillozzi, S.; Dell'Orto, M.C.; Cazzaniga, G.; Arcangeli, A.; Kronnie, G.T.; Basso, G. Hepatocyte growth factor receptor c-met is associated with fas and when activated enhances drug-induced apoptosis in pediatric $\mathrm{b}$ acute lymphoblastic leukemia with tel-aml1 translocation. J. Biol. Chem. 2007, 282, 29384-29393.

148. Sequist, L.V.; von Pawel, J.; Garmey, E.G.; Akerley, W.L.; Brugger, W.; Ferrari, D.; Chen, Y.; Costa, D.B.; Gerber, D.E.; Orlov, S.; et al. Randomized phase ii study of erlotinib plus tivantinib versus erlotinib plus placebo in previously treated non-small-cell lung cancer. J. Clin. Oncol. 2011, 29, 3307-3315. 
149. Spigel, D.R.; Ervin, T.J.; Ramlau, R.A.; Daniel, D.B.; Goldschmidt, J.H., Jr.; Blumenschein, G.R., Jr.; Krzakowski, M.J.; Robinet, G.; Godbert, B.; Barlesi, F.; et al. Randomized phase II trial of onartuzumab in combination with erlotinib in patients with advanced non-small-cell lung cancer. J. Clin. Oncol. 2013, 31, 4105-4114.

150. Stinchcombe, T.E. Novel agents in development for advanced non-small cell lung cancer. Ther. Adv. Med. Oncol. 2014, 6, 240-253.

151. Parums, D.V. Current status of targeted therapy in non-small cell lung cancer. Drugs Today 2014, 50, 503-525.

152. Goodman, S.L.; Picard, M. Integrins as therapeutic targets. Trends Pharmacol. Sci. 2012, 33, 405-412.

(C) 2015 by the authors; licensee MDPI, Basel, Switzerland. This article is an open access article distributed under the terms and conditions of the Creative Commons Attribution license (http://creativecommons.org/licenses/by/4.0/). 